\title{
Subiektywne poczucie satysfakcji życiowej osób starszych
}

\section{KEYWORDS}

life satisfaction, old age, elderly people

\begin{abstract}
Joanna Gregorczuk-Prosicka, Subiektywne poczucie satysfakcji życiowej osób starszych [Older people's subjective sense of life satisfaction]. Kultura - Społeczeństwo - Edukacja nr 1(19) 2021, Poznań 2021, pp. 145-159, Adam Mickiewicz University Press. ISSN 2300-0422. DOI 10.14746/kse.2021.19.11
\end{abstract}

Life satisfaction is a complex and highly subjective concept. Scholars studying this issue have made numerous attempts to define it. Whether we are happy, or have a sense of fulfilment, or we delight in the years we have lived through and in everyday life, it is all related to the aforementioned life satisfaction. The article deals with the subjective sense of life satisfaction among elderly people who are members of the Senior Club in a rural-urban district. The article is based on material obtained from in-depth interviewing. The research objective was to explore and obtain thorough knowledge of the sense of life satisfaction of elderly people. Particular attention is paid to selected factors that determined the perception of life satisfaction. On the basis of the participants' opinions, certain groups of factors were selected that were more often indicated as key factors in the assessment of life satisfaction, i.e. health, housing situation, place of residence, family relations, neighbourly relations and a sense of social utility. The article presents the complexity of the problem and the need for an individual approach to the topic, due to the changing face of ageing and old age.

* ORCID: https://orcid.org/0000-0003-4366-2250. 


\section{Wprowadzenie}

W pracach naukowych oraz w dyskusjach społecznych zagadnienie starości staje się coraz częściej przedmiotem zainteresowań przedstawicieli różnych dyscyplin naukowych. Starość, jako końcowy etap życia człowieka, jest różnie postrzegana. Jest wiele opinii, które przeczą pozytywnemu wizerunkowi osoby starszej. Można usłyszeć stwierdzenie, że starość się Panu Bogu nie udała. Poniższy tekst ma na celu rozpoznanie stanu poczucia satysfakcji życiowej oraz wskazanie, jakie czynniki kształtują poczucie satysfakcji życiowej osób starszych. W licznych badaniach autorzy zwracają uwagę na rolę zasobów osobistych i społecznych w procesie starzenia się (np. Pinquart, Schindler, 2007; Swagler, Jome, 2005). Dzięki pewnym dyspozycjom osobowościowym, predysponującym do pozytywnej bądź negatywnej oceny własnego życia, starzenie się może w większym bądź mniejszym stopniu wpływać na poczucie satysfakcji z życia w tym okresie.

Bogate piśmiennictwo, liczne badania empiryczne i obszerne opracowania naukowe świadczą o wieloaspektowości i interdyscyplinarności wiedzy zdobytej na temat starości (Halicka, 2004, 2018; Steuden, Marczuk, 2006; Szatur-Jaworska, Błędowski, Dzięgielewska, 2006; Kijak, Szarota, 2013; Halicka, Halicki, Kramkowska, 2016; Dubas, Muszyński, 2016; Błachnio, 2017, 2019). Jeśli porównamy zasób wiedzy o tym etapie życia z innymi, to okazuje się, że o starości i o samym procesie starzenia się wiemy dzisiaj wiele. W najprostszym ujęciu starość rozumiana jest jako stan, jako ostatni etap życia, natomiast starzenie się jest procesem, który nieuchronnie kończy się śmiercią (Zych, 2006). Zgodnie z definicją Światowej Organizacji Zdrowia człowiek stary to osoba po 60. roku życia. W literaturze odnaleźć można liczne definicje starzenia się, jednakowoż przedmiotem zainteresowania artykułu jest nie tyle wcześniej wspomniana starość, ile odczuwanie satysfakcji życiowej w tym okresie.

Celem niniejszej pracy jest przedstawienie subiektywnych ocen dotyczących satysfakcji życiowej osób starszych, będących członkami Klubu Seniora na terenie gminy miejsko-wiejskiej. Przeprowadzone badania przybliżą obraz tego, jak ludzie starsi postrzegają otaczającą rzeczywistość, co w ich ocenie ma związek z odczuwaniem satysfakcji życiowej oraz z czym osobom starszym kojarzy się poczucie satysfakcji w okresie starości. Punktem wyjścia prezentowanej pracy będzie wyjaśnienie i omówienie pojęcia satysfakcji życiowej, następnie pokrótce zostaną przedstawione założenia badawcze. Całość pracy zamyka próba analizy badań przeprowadzonych wśród członków Klubu Seniora dotyczących satysfakcji życiowej oraz czynników, które narratorzy wskazywali najczęściej jako decydujące o jej poczuciu. 


\section{Pojęcie satysfakcji życiowej w literaturze}

W literaturze polskiej i zagranicznej istnieje wiele definicji satysfakcji życiowej, nazywanej również jakością życia, ogólnym zadowoleniem z życia, dobrostanem, dobrobytem, dobrym samopoczuciem lub po prostu szczęściem (Czapiński, 2004; Derbis, 2008; Halicka, 2004; Steuden, Marczuk, 2006; Timoszyk-Tomczak, Bugajska, 2013; Kijak, Szarota, 2013; Błachnio, 2019). Pluralizm definicyjny może wynikać $\mathrm{z}$ interdyscyplinarnego charakteru pojęcia satysfakcji życiowej. Tą tematyką zajmują się badacze z zakresu różnych dziedzin - między innymi psychologii, pedagogiki, filozofii, medycyny, socjologii czy ekonomii społecznej (Papuć, 2011).

Termin „satysfakcja życiowa” wywodzi się z języka łacińskiego - satisfactio, pierwotnie oznaczało to zadośćuczynienie lub spełnienie życzenia drugiej osoby (Dubisz, 2003). Samo słowo „satysfakcja” ewoluowało przez wiele wieków, w Słowniku języka polskiego jedno z jego znaczeń to „zadośćuczynienie za wyrządzoną krzywdę". Jednak przyjęło się, i wielu autorów w ten sposób definiuje, iż satysfakcja z życia to uczucie przyjemności, zadowolenia, spełnienia (Czapiński, 2004; Zalewska, 2003; Halicka, 2004; Błachnio, 2019). To wedle myśli J. Locka, zadowolenie z życia wziętego w całości (Kuziak i in., 2011). Jedna z pierwszych powstałych na świecie definicji sformułowana przez Dalkey’a i Rourke’a mówi, iż satysfakcja z życia i poczucie szczęścia to dwie główne składowe jakości życia (1972). Ewoluowanie pojęcia „satysfakcja z życia” zostało zaprezentowane i omówione w monografii Małgorzaty Halickiej, pt. Satysfakcja życiowa ludzi starych (2004). Autorka zwróciła uwagę na genezę powstania oraz różnorodność językową pojęcia; ewolucję oraz złożoność definicji. W książce odnajdziemy bogactwo zagadnień teoretycznych dotyczących starości oraz poczucia satysfakcji życiowej, ale przede wszystkim wyniki długoletnich i złożonych badań dotyczących poruszanego problemu, tj. satysfakcji życiowej ludzi starszych.

W literaturze nie ma jednej definicji „satysfakcji życiowej”. Często używane są zamiennie terminy „jakość życia”, „zadowolenie z życia”. W niniejszym artykule pojęcia „satysfakcja życiowa” oraz „jakość życia” są traktowane jako tożsame, gdyż obydwa terminy wskazują na dobrostan (ang. well-being), którego miernikiem jest osobisty rozkwit i życie pełnią życia (np. Seligman, 2008; Halicka, 2004: 15).

Na przełomie XX i XXI wieku definicja satysfakcji życiowej została znacznie rozbudowana i doprecyzowana, jednak by móc zrozumieć coś bardziej skomplikowanego, należy skupić się wpierw na podstawie, a całą definicję rozłożyć na czynniki pierwsze - czyli pojąć i zdefiniować najpierw, czym jest szczęście jako nieodłączny element odczuwania satysfakcji. Psychologia pozytywna, obok terminu „satysfakcja”, wskazuje pojęcie „szczęścia”, szczęścia rozumianego jako per- 
manentny stan, a nie chwilowa emocja. Romuald Derbis zauważa, że współcześnie dominuje antropocentryczna orientacja w rozumieniu szczęścia. Nawiązuje ona do antycznego dionizyjskiego sposobu jego pojmowania, polegającego na zabieganiu o szczęście (Derbis, 2008: 110) Dionizyjski typ szczęścia w kulturze Zachodu wiąże się z indywidualizmem, aktywną postawą wobec życia, które jest dziełem człowieka, a nie bóstw czy innych istot nadprzyrodzonych.

Uniwersalny słownik języka polskiego (Dubisz, 2003: 1502-1503) podaje trzy znaczenia słowa „szczęście”:

1) „pomyślny los, powodzenie w jakichś przedsięwzięciach, sytuacjach życiowych itp.; pomyślność, powodzenie";

2) „uczucie zadowolenia, upojenia, radości; szczęśliwość; także: to wszystko, co wywołuje ten stan";

3) „zbieg, splot pomyślnych okoliczności, szczęśliwe zrządzenie losu, pomyślny traf, przypadek".

Poczucie szczęścia oznacza najwyższy stopień zadowolenia z życia w ocenie subiektywnej (Kanasz, 2015: 23-24). Szczęście subiektywne czy też dobrostan subiektywny jest zadowoleniem z życia jako całości oraz z istotnych jego sfer. Jako przyczyny i korelaty szczęścia literatura wskazuje czynniki biologiczne, psychospołeczne oraz zdarzenia losowe, cechy osobowości, czynniki polityczno-ekonomiczne, małżeństwo (związki), częstotliwość kontaktów towarzyskich, zatrudnienie i wysokość dochodów, wykształcenie, aktywność w czasie wolnym, religia, wyznanie, negatywne zdarzenia życiowe, sposoby radzenia sobie z negatywnymi zdarzeniami, obiektywny stan zdrowia, wiek i płeć. Lista została sporządzona na podstawie analiz dokonanych przez M. Argylego (2004), J. Czapińskiego (2004, 2017), M. Seligmana (2008), P. Boskiego (2010), R.B. Nesa i E. R pysamba (2016). Choć poruszany temat był obiektem zainteresowania i analizy wielu badaczy, nadal jednak budzi zainteresowanie.

E. Skrzypek w swoim artykule pisze, że jakość życia człowieka to „suma jego starań, zmagań, walki toczonej często z samym sobą, to umiejętność dokonywania trafnych wyborów, to także zdolność do kompromisów, to przede wszystkim umiejętność podejmowania decyzji i przyjmowania ich konsekwencji z całą odpowiedzialnością" (Skrzypek, 2000: 21). Autorka dodatkowo wymienia, iż na jakość życia ma wpływ również to, jak widzą nas inni. Pojęcie jakości życia jest bardzo szerokie i obejmuje zarówno wartości materialne, jak i niematerialne oraz duchowe. Komponenty jakości życia dzielą się na dwie podstawowe grupy - czynniki obiektywne oraz czynniki subiektywne (Czapiński, 1992, za: Halicka, 2004: 22). Obiektywne, tj. dochód, sytuacja zdrowotna, poziom zdobytego wykształcenia czy warunki mieszkaniowe są to wskaźniki będące źródłem porównań z innymi oso- 
bami. Subiektywne natomiast odnoszą się do osobistych odczuć jednostki ujmowanych w kategoriach zadowolenia. W tej grupie wskaźników odnajdziemy m.in.: zadowolenie z życia, satysfakcję, poczucie własnej wartości i sensu życia czy poczucie spełnienia w szerszej działalności społecznej.

W literaturze można wyróżnić trzy grupy wyznaczające sposób pojmowania i badania satysfakcji i jakości życia. Pierwsza z grup to teorie ukierunkowane na zaspokajanie potrzeb i na osiąganie celów. W tym podejściu poziom życia rozpatruje się w kategoriach zaspokajania określonych uniwersalnych potrzeb człowieka. Zakłada się, że ludzie oceniają pewne sfery życia w bardzo podobny sposób, że istnieje pewien „pakiet”, który zawiera w sobie warunki życiowe, w których tkwi każdy człowiek. Dodatkowo ta pierwsza grupa teorii mówi, iż źródłem szczęścia człowieka jest redukcja napięcia. Drugi blok teorii to teorie procesu, inaczej działania. W tym podejściu kładzie się nacisk na przebieg procesów poznawczych, które stanowią podstawę indywidualnej percepcji satysfakcji z życia. Człowiek stanowi główne i jedyne kompetentne źródło informacji o własnym poczuciu szczęścia, które jest zespołem warunków życiowych. Trzecią, ostatnią grupę teorii stanowią teorie predyspozycji genetycznych i osobowościowych. Ta grupa koncepcji doszukuje się trwałości i stabilności poczucia szczęścia w czynnikach natury genetycznej. Ludzie są w pewnym sensie predysponowani do bycia szczęśliwymi lub nie (Czapiński, 2004).

Istnieje wiele teorii dotyczących pojęcia satysfakcji życiowej, na przestrzeni lat termin ten ewoluował i zmieniał swoje znaczenie. Współczesna, wciąż rozwijająca się terminologia, najlepiej odzwierciedla dzisiejsze rozumienie satysfakcji życiowej. Satysfakcja z życia to ogólna ocena zadowolenia z życia konkretnej osoby odnoszona do osobistych standardów. Sprzyja aktywności i lepszemu radzeniu sobie z trudnymi sytuacjami (Jachimowicz, Kostka, 2009). Ocena satysfakcji życiowej jest wynikiem porównania osobistej sytuacji z określonymi przez siebie standardami na podstawie własnych kryteriów. Jest to świadomy, poznawczy proces globalnej oceny życia (Świerżewska, 2010). Taką też definicję przyjęłam na potrzeby swoich badań.

\section{Założenia metodologiczne badań własnych}

Badania były prowadzone wśród członków Klubu Seniora na terenie gminy wiejsko-miejskiej (22 tys. mieszkańców), który działa przy Ośrodku Pomocy Społecznej. Badania o charakterze jakościowym były prowadzone w kwietniu 2017 roku. Zostały zrealizowane $w$ ramach pracy magisterskiej. Celem badań było pogłębie- 
nie wiedzy na temat satysfakcji życiowej osób starszych aktywnych społecznie; poszukiwanie odpowiedzi na pytanie, jakie czynniki decydują o poczuciu satysfakcji. Prezentowane imiona osób badanych zostały w pracy zamienione. Przebadanych zostało 10 osób w wieku 64-86 lat, w tym dziewięć kobiet oraz jeden mężczyzna. Osoby do wywiadów zostały wskazane przez prowadzące Klub Seniora, a proporcje związane z płcią rozmówców nie są przypadkowe. Wśród 33 członków Klubu Seniora jest 30 pań i 3 panów, proporcje zastosowane w grupie badanych $(9: 1)$ odzwierciedlają stan faktyczny.

Metodą wykorzystaną podczas prowadzenia badań było wielokrotne studium przypadku. Jego cechą charakterystyczną jest możliwość studiowania kilku przypadków jednocześnie oraz możliwość opisu nietypowych zjawisk, zdarzeń, procesów, ludzi. Zastosowanie tej metody umożliwiło realizowanie przyczynkowych badań nad satysfakcją życiową, która jest niezwykle złożonym zjawiskiem i odnosi się do wysoce zindywidualizowanych odczuć osób aktywnych społecznie. Wielokrotne studium przypadku opiera się na obszernej analizie badanego problemu, ale też na lepszym zrozumieniu zachodzących procesów (Konecki, 2000). Wykorzystanie pogłębionych wywiadów indywidualnych pozwoliło na pogłębienie wiedzy na temat badanego zjawiska.

Wywiady toczyły się wokół jednego zasadniczego zagadnienia, tj. poczucia satysfakcji życiowej osób starszych. Rozmówcy kolejno odpowiadali na pytania dotyczące subiektywnej oceny satysfakcji życiowej poprzez omówienie poszczególnych wskaźników, tj. stanu zdrowia, relacji z rodziną i osobami bliskimi, sytuacji mieszkaniowej i materialnej, hierarchii potrzeb indywidualnych i realizacji celów życiowych, oceny przeszłości pod kątem osiągnięć, powodów do dumy; relacji sąsiedzkich, wiary, roli Kościoła w życiu oraz aktywności społecznej (za: Halicka, 2004: 34-40). Dalej zostaną poddane analizie następujące wskaźniki satysfakcji życiowej: subiektywna ocena zdrowia, sytuacja mieszkaniowa, miejsce zamieszkania, relacje rodzinne, relacje sąsiedzkie oraz poczucie użyteczności społecznej.

\section{Próba analizy satysfakcji życiowej osób starszych na podstawie wybranych wskaźników}

Osoby starsze uczestniczące w badaniach wskazywały jednogłośnie, że posiadanie dobrego zdrowia rzutuje głównie na odczuwanie satysfakcji życiowej. Jeśli jest zdrowie, to jest wszystko (Irena, 78 1.). Kwestia samopoczucia jest czymś indywidualnym, według definicji Światowej Organizacji Zdrowia (WHO) zdrowie to uzyskanie dobrego samopoczucia zarówno na poziomie fizycznym, psychicznym, jak 
i społecznym. To nie tylko brak choroby czy niepełnosprawności, ale harmonia całego układu biologiczno-psychiczno-społeczno-środowiskowego.

Subiektywną ocenę stanu zdrowia wśród opinii badanych różnicowała przede wszystkim dostępność lekarzy specjalistów. Seniorzy mieszkający samotnie mają nieraz utrudnione dostanie się na umówią wizytę u lekarza, a perspektywa samodzielnej podróży PKS do miasta wojewódzkiego, w którym przyjmują lekarze specjaliści, może być przytłaczająca, co wynika z przytoczonej wypowiedzi. Jedna $\mathrm{z}$ badanych o problemie $\mathrm{z}$ dojazdami do lekarza wypowiada się tak:

Jak idę do mojego lekarza rodzinnego, to sama wezmę wózeczek i pójdę. Ale jak już mam umówiona wizytę do kardiologa czy okulisty, to muszę wcześniej córkę powiadomić $i$ ona wtedy bierze urlop $w$ pracy $i$ wiezie mnie. Też musi i czas poświęcić, i pracę, i nieraz nie chce już jej prosić. A sama też nie pojadę (Krystyna, 82 1.).

Co ciekawe, inna badana - 78-letnia kobieta, wspomina, że w miejscowości, w której mieszka, jest człowiek, który trudni się dowożeniem ludzi do lekarzy w zamian za zapłatę. Ma jasno określone stawki, które wszystkim mieszkańcom wsi są znane i akceptowalne przez nich. Mówi:

Ja widzę pani zdziwienie na twarzy (śmiech) i rozumiem, że taki układ może dziwić, że on wykorzystuje starszych. Moim córkom też to się nie podoba. No ale zobaczy pani, skoro to ma stużyć starszym ludziom, co samotnie $w$ domach mieszkaja, to co w tym złego? Nam to nie przeszkadza (Irena, 78 1.).

W ocenie narratorki jest to dowód na pozytywne i zażyłe relacje sąsiedzkie.

Sytuacja mieszkaniowa świadczy o poziomie życia i statusie społecznym człowieka. Wśród narratorów pojawiały się różne głosy na temat indywidualnej oceny warunków mieszkaniowych. Jedni oceniali sytuację mieszkaniową jako dobrą lub bardzo dobrą, upatrując w tym poczucie bezpieczeństwa i komfortu, inni natomiast, pomimo XXI wieku, wskazywali na warunki, które znacznie odbiegają od minimalnych standardów. Jedna z narratorek mówi:

Był jeden pan, chciał kupić moją chałupkę, że zamienić na blok chciał. Było nawet kilka kupców i to było trzeba sprzedać $i$ iść do bloku i bym miała życie. Ale co jak człowiek głupi był. A teraz jakie moje życie? Może tych takich bóli by nie było (badana cierpi na reumatyzm), bo w bloku i łazienka, i ciepło, i nie trzeba opalać. A jak mnie teraz już pod wiosnę piecyk zaczą dymić, wie pani? Toż to strach i piecyk już popękany. Za co ja remont zrobię? (Henryka, 73 1.). 
Kolejna badana, pani Teresa (76 1.), o swoich warunkach mieszkaniowych na wsi mówi tak:

Dach jednospadowy, bo to plan na budynek gospodarczy byt, jeszcze mamusia zrobiła. Trzy pomieszczenia, środkiem kuchnia, dwa pokoiki. To tylko w jednym piecyk kaflowy jest, stupek i ja opalam tam. Studnia na dworze, toaleta na dworze. To wie pani jak ja miałam po operacjach dobrze? Po tych biodrach [po operacji stawu biodrowego] 5 stopni schodów i wychodzić i wchodzić ciężko na tych kulach mnie było... A jak pranie w sobotę robię, to wodę wiadrami ciagam $z$ podwórka.

W przypadku obydwu badanych ciężkie warunki mieszkaniowe bezpośrednio przekładały się na niskie poczucie satysfakcji życiowej. Oczywiście był to jeden z kilku czynników, ale miał charakter kluczowy. Złe warunki mieszkaniowe mają zazwyczaj jedną przyczynę - złą sytuację materialną. Nierzadko też wśród narratorów to samotność lub niepełnosprawność była uzasadnieniem oceny złych warunków mieszkaniowych. Znacznie częściej niż przyczyny wskazywane były konsekwencje wiążące się ze złą sytuacją mieszkaniową, jeśli takowe występowały. Wypowiedzi osób uczestniczących w badaniach rodzą wniosek, iż żadna osoba starsza nie czuje się komfortowo w gospodarstwie domowym, które nie zaspokaja jej podstawowych potrzeb. Ponadto narratorzy wskazywali na związek pomiędzy słabymi warunkami mieszkaniowymi a pogorszeniem stanu zdrowia. Co w ich ocenach bezpośrednio przekładało się na obniżenie satysfakcji życiowej. Wśród uczestników badań pozytywna ocena warunków zamieszkania w dużej mierze była spowodowana wspólnym zamieszkaniem jednego budynku przez rodzinę wielopokoleniową (badana osoba starsza wraz ze zstępnymi) lub po prostu wysoki status materialny. Takie wnioski narodziły się w toku badań, natomiast wyniki badań prowadzonych przez Wojciecha Pędicha wskazują na ogromne zróżnicowanie w subiektywnych ocenach warunków mieszkaniowych i związanym z nimi stanem zdrowia. Analizy prowadzone w 2002 roku wskazywały, że pomimo subiektywnie negatywnej oceny warunków zamieszkania respondenci deklarowali wysoki stan zadowolenia $\mathrm{z}$ własnego zdrowia oraz wysoki wskaźnik satysfakcji życiowej (Pędich, 2002).

Wśród odpowiedzi znalazły się również pozytywne oceny sytuacji mieszkaniowej, pozwalające odnaleźć w nich źródło satysfakcji życiowej. Między innymi pani Irena, która od lat jest osobą samotnie gospodarującą, mówi:

Ja to na przykład mam swój domeczek sidingiem obity, a w połowie nie - sa deski. I teraz trzeba go pomalować. Malarza szukam, malarza nie ma. Ale wie 
pani? Mnie to nie przeszkadza, kiedyś to człowiek byt młodszy to i to by się chciato, i to. A teraz... Jakie mebli stoją, takie stoja - dobrze. W tamtym roku córka była to pralkę nowa, automat kupiła. Ja nie chciałam, bo ja całe życie miałam „Franię” i mnie najlepiej $z$ „Franią". Nie - ona musi automat. Kupili automat. Gaz mam, mikrofalówkę mam, czajnik elektryczny mam. Już mnie nic nie trzeba. Mam wszystko, czego potrzebuję (Irena, 78 1.).

Dobre warunki mieszkaniowe osób starszych często wiążą się z zamieszkiwaniem przez nich w rodzinach międzypokoleniowych. Opinia pani Marianny:

Tak jak dla mnie jednej osoby to mam bardzo dobre warunki. Mam pokoik, to moja sypialka. Mam kuchnie, mam oddzielna łazienkę, mam swoje centralne. Naprawdę nie mam na co narzekać, bo jak tak się postucha jak ludzie mają, to maja opłakane warunki. A to jest nowy dom $z$ cegły, tak że nie ma żadnych tam powikłań zdrowotnych czy innych, że ja tam mam jakieś zmartwienie o dom. Jest dobrze (Marianna, 71 l.).

Pani Marianna zamieszkuje wraz z synem, synową oraz wnukami, a nowy dom, o którym wspomina, przed paroma laty został wybudowany właśnie przez jej syna. Zapewnił on matce oddzielne, niezależne wejście oraz komfortowe pomieszczenia. Rozmowy z seniorami prowadzone w ramach badań wskazują na to, iż nie mają oni wygórowanych wymagań, co do standardów mieszkaniowych. Częściej wyznacznikiem ich zadowolenia i satysfakcji w kontekście miejsca zamieszkania czy warunków mieszkaniowych jest poczucie komfortu i bezpieczeństwa, dostęp do infrastruktury oraz dobre sąsiedztwo (Halicka, 2004). Jedna z rozmówczyń niestety nie odnajduje spokoju na tej płaszczyźnie, mówi tak:

Czyżby nie było miło, jak ja bym zajechała tam do tych $X$ [miejscowość, w której znajduje się dom rodzinny narratorki] $i$ byśmy usiedli, porozmawiali? Przecież tam wszyscy moi sasiedzi, mój pokoik, moje rzeczy. Ja tam całe życie zostawiłam... Ale co, jak syn mnie tam już nie chce (Henryka, 73 1.).

Przy omówieniu historii pani Henryki należałoby poruszyć temat zwaśnionych rodzin wielopokoleniowych zamieszkujących wspólnie. W przypadku narratorki na ich rodzinnych sporach ucierpiała najbardziej właśnie ona. W sytuacji konfliktu rodzinnego prawa osób starszych są najmniej respektowane, a ich potrzeby nie są brane pod uwagę. Seniorzy dopasowują się do zaistniałej sytuacji, ulegają, nie biorą udziału w podejmowaniu rodzinnych decyzji, nikt ich nie pyta o zdanie, po pro- 
stu są. Wśród osób starszych biorących udział w badaniach zdecydowana większość stwierdza, że nie angażuje się w życie i decyzje młodszych pokoleń. Analiza materiału empirycznego pozwoliła na sformułowanie wniosku, iż w przypadku wykluczenia osoby starszej z życia rodzinnego nie odczuwa ona komfortu psychicznego, a co za tym idzie - jej satysfakcja z życia znacznie spada. To sprowadza uwagę do kolejnego, kluczowego czynnika determinującego poczucie satysfakcji życiowej, czyli oceny relacji rodzinnych i pozarodzinnych kontaktów społecznych.

Okres starości przysparza ludziom wiele nowych ról społecznych, opartych głównie na sieci wzajemnych powiązań w rodzinie i z osobami bliskimi, stają się oni teściami, dziadkami, pradziadkami, starszymi i bardziej doświadczonymi przyjaciółmi swoich młodszych znajomych (Braun-Gałkowska, 2006). Wśród narratorów fakt wejścia w rolę dziadka czy babci był jednoznacznie źródłem satysfakcji bez względu na miejsce zamieszkanie (wspólnie z rodziną lub samodzielnie). Prawie każdy z badanych zapytany o rodzinę i bliskich ożywał, ochoczo opowiadał i dzielił się doświadczeniem. Obszerne wyniki badań na temat relacji rodzinnych osób starszych przedstawiła w swojej monografii dotyczącej satysfakcji życiowej seniorów Małgorzata Halicka, wskazując na odczuwanie potrzeby pielęgnacji tych więzi przez osoby w podeszłym wieku (2004).

Wybitna przedstawicielka polskiej gerontologii - Zofia Szarota - proponuje bardzo ciekawą typologię ról społecznych pełnionych przez osoby starsze (Szarota, 2013: 19-22). Autorka wyznacza trzy zasadnicze obszary ról; w przypadku prowadzonej analizy najbardziej interesujące są role rodzinne. W obszarze ról związanym z przynależnością do grupy pierwotnej autorka wyróżnia role rodzinne wynikające z pokrewieństwa: córka/syn, matka/ojciec, babcia/dziadek, brat/siostra oraz wynikające ze spowinowacenia: żona/mąż, teściowa/teść, bratowa/szwagier itd. W obszarze tych ról oczekuje się od starszego członka rodziny m.in. rozwagi, mądrości w rozstrzyganiu sporów, pomocy zwłaszcza psychicznej w trudnych dla rodziny chwilach. W przypadku ról rodzinnych starość przynosi odwrócenie układu relacji. Starsi ludzie, funkcjonujący do niedawna jako opiekunowie, żywiciele, mentorzy i wychowawcy, teraz sami zaczynają potrzebować wsparcia i opieki dotychczasowych podopiecznych (Szarota, 2013: 19). Typologia przedstawiona przez autorkę znalazła odzwierciedlenie w wypowiedziach przebadanych osób starszych, gdyż seniorzy bardzo często wskazywali na obawę przed odwróceniem ról. Zapytani o nadzieje i marzenia jednogłośnie odpowiadali, by nie musieć być zależnym od dzieci, synowych czy zięciów.

Potwierdzeniem słów o istotności relacji rodzinnych w życiu seniorów są ich wypowiedzi. Badani rozmówcy o relacjach z rodziną wypowiadali się między innymi tak: 
Jestem bardzo Bogu wdzięczna za takie dzieci i za taka rodzinę, i każdego dnia Bogu za nich dziękuję. Bo jak miałam dwie córki i dwóch synów to sq wszyscy aktywni zawodowo i sa wszystkie pożenione, mają rodziny założone. Nie maja żadnych nałogów, nie włócza się, nie zajmują się jakimiś tam pijaństwami czy niepotrzebnymi kolegami. To jest od Boga dar! (Marianna, 71 1.).

Kolejna z badanych przedstawia sprawę w taki sposób:

Córka, z która mieszkam, ta co jest tutaj, jest taka bardzo opiekuńcza. Ja zawsze moge na nia liczyć. Najpierw ja pomagałam jej przy wychowaniu dzieci, bo ona ma trójkę dzieci, a teraz ona się mna zajmuje, gdy jest taka potrzeba (Krystyna, 82 1.).

Jednak nie wszyscy seniorzy mają to szczęście, by mieć bliskie osoby przy sobie i móc zawsze liczyć na ich wsparcie w trudnych chwilach.

$\mathrm{Na}$ kwestię poczucia osamotnienia zwrócił uwagę Jerzy Halicki w swej książce Obrazy starości rysowane przeżyciami seniorów, wskazując na intensywne przeżywanie samotności przez osoby starsze. Autor podkreślił, iż wśród przebadanych osób, których kontakty rodzinne nie były poprawne, można było zauważyć pewną intensyfikację kontaktów pozarodzinnych. Co prowadzi do wniosku, iż satysfakcję życiową można czerpać zarówno z bliskich kontaktów z rodziną, ale również (a może głównie) z relacji ze społecznością lokalną (Halicki, 2010). Jedna z narratorek stwierdziła, że dobry sąsiad lepszy niż niejeden krewny (Jadwiga, 84 1.). Pani Irena (78 1.) opowiedziała w wywiadzie historię w ciekawy sposób ilustrującą relacje sąsiedzkie:

Myśmy jak z mężem młodzi byli, to jeszcze gospodarka była 19 ha. Dzieci małe, a my żeby zarobić na budowe nowego domu, po nocy jeszcze szyliśmy. A i marynarki, i futra, i sukienki, i koce tkaliśmy. To u nas żadnego wieczoru nie było pustego domu! Prosze mi wierzyć, wszyscy sasiedzi się schodzili. I my tak do późnej nocy potrafiliśmy siedzieć, mężczyźni grali w karty, a kobiety plotkowały i wyszywały i śpiewy były. (śmiech) Jeszcze w małej chatce mieszkaliśmy z męża rodzicami. Tam mowy nie było o tym, żeby kogoś wyprosić. A teraz? Parę dni wcześniej trzeba się zapowiadać z wizytą. A jak przyjdziesz bez zaproszenia, to jeszcze urazisz gospodarzy.

Czasy i ludzie się zmieniają, natomiast relacje, dobre relacje sąsiedzkie były (i są nadal) źródłem satysfakcji z życia osób starszych uczestniczących w badaniach. 
Jako egzemplifikację i podsumowanie kwestii pozarodzinnych kontaktów społecznych oraz czerpania $\mathrm{z}$ nich satysfakcji życiowej przedstawię punkt widzenia jednej z narratorek. Marianna (71 l.) od kilkunastu lat jest sołtysem niewielkiej miejscowości. Z zajmowanej pozycji czerpie wyjątkową satysfakcję, a swoje relacje ze społecznością lokalną ocenia nienagannie, na co - jak sama mówi - długo pracowała. Zapytana o kontakty społeczne, o relacje z sąsiadami, odpowiedziała:

Bardzo, bardzo dobre. To nie chodzi o to, że tylko $z$ sasiadami, ale nawet $z$ sasiednimi wsiami! Jestem bardzo mile widziana wszędzie, dlatego że ja bardzo wszystkich ludzi szanuje. Zacząć od maleńkiego w kołysce, a na najstarszym skończyć. Nie odmówię żadnej pomocy nikomu! To moga stwierdzić sąsiedzi i w mojej wsi, iz okolicznych wsi. (...) Nawet, wie pani, jak stoję na podwórku, to sa nawet takie sąsiady, że jada do (...) [najbliższe miasto] i zatrzymają się $i$ „czy może coś potrzeba?”, „może podwieźć?”. No po prostu nie moge nic negatywnego powiedzieć na swoje życie w tej wiosce. No jak już coś tam mówia na mój temat złego i to do mnie to dochodzi... Jak coś poplotkują.. To daj im Boże, no... (śmiech). Ja nie mam im tego za złe. (...) Ja nie uważam takiego człowieka, który zamknie się w czterech ścianach i do nikogo nie wychodzi, to od razu można zgłupieć. Człowiek musi mieć kontakt z drugim człowiekiem, musi wyjść, musi z kimś porozmawiać. Czy czasem jakieś nawet nieprzyjemne słowo uslyszeć - to też jest potrzebne, bo musi jakiś taki się $w$ czlowieku zbudzić.... Jak to można powiedzieć... taka złość, taka intryga... Jak to się mówi „o podniosło mi to słowo ciśnienie”. Tego też człowiek potrzebuje. Bez ludzi człowiek się nie urodzit i bez ludzi ze świata nie schodził. (...) Dla mnie to jest ogromna satysfakcja, jak ja coś dokonałam, jak cośzrobiłam, jak coś zaplanowałam i mnie to wyszło, jak komuś pomogłam i ktoś to docenit. Wtedy jestem bardzo zadowolona. I wie pani co? I wtedy po prostu idę na głowę, bo jestem z tego zadowolona i tego pewna, że ja coś zrobiłam nie tylko dla siebie, ale też dla bliźniego. Bo swoje potrzeby spetniać to mój obowiazek, ale już dla kogoś - to dobra wola. (...) Pót roku chowałam obcą kobietę, nad która się syn z synową znęcat. Pod swój dach ja przygarnęłam, grosza za to nie wzięłam, wszystko robiłam dla niej i podziękowania nawet nie dostałam. Takie jest życie. Ale ja przez to satysfakcje odczułam i swój katolicki obowiązek spełniłam, sumienie mam czyste (...).

Narratorzy na pytanie: „Czy kontakty z innymi ludźmi są ważne?” bez zastanowienia odpowiadali, że tak. Najczęściej wskazywali na konieczność pielęgnowania dobrych relacji w perspektywie całożyciowej oraz przedstawiali liczne profity wynikające $\mathrm{z}$ tych relacji. Wszystkie przebadane osoby starsze, bez wyjątku, w pozarodzinnych kontaktach społecznych odnajdywały radość i satysfakcję z życia. 


\section{Zakończenie}

Starość jako okres życia, mimo iż jest tematem rozpraw wielu naukowców, nadal pozostaje w sferze zainteresowań takich nauk, jak socjologia, pedagogika, psychologia, ekonomia czy medycyna. Wszystkie zjawiska związane bezpośrednio z opiniami ludzi i ich indywidualnymi odczuciami zmieniają się, potrzebują zatem ponownej weryfikacji i uaktualnienia. Takim zjawiskiem jest odczuwanie satysfakcji życiowej. Mimo iż temat cieszy się dużą popularnością wśród naukowców, jego ciągłe zgłębianie przynosi coraz to nowsze i obszerniejsze rezultaty. Dokonane analizy wskazują na złożoność poruszonego tematu oraz wysoce zindywidualizowany charakter zjawiska. Satysfakcję życiową każdy odczuwa poprzez szereg innych czynników wzajemnie na siebie oddziałujących. Nie można jednoznacznie stwierdzić, który z nich ma największe znaczenie, ponieważ każdy człowiek jest inny oraz ma inne wartości.

W przeprowadzonych badaniach zgłębiono wiedzę na temat poczucia satysfakcji życiowej wśród osób starszych. Analiza wyników badań potwierdziła złożoność problemu oraz potrzebę zindywidualizowanego podejścia do tematu. Oznacza to, że na odczuwanie satysfakcji z życia składa się wiele czynników, które są od siebie zależne oraz wzajemnie na siebie oddziałują. Dla jednych do poczucia spełnienia i uzyskania spokoju ducha brakowało jedynie dobrych relacji rodzinnych, a inni z bliskich kontaktów z dziećmi i wnukami czerpali największą satysfakcję. Jedni usprawiedliwiali swoje niezadowolenie $\mathrm{z}$ obecnej sytuacji życiowej słabą sytuacją materialną i mieszkaniową, a drudzy pomimo obiektywnie złych warunków mieszkaniowych deklarowali wysoki poziom satysfakcji z życia. Poczucie satysfakcji życiowej - jak można zauważyć - może przyjąć różną postać. Istotnym jest to, by chcieć poznać złożoność problemu, a w przyszłości wyjść naprzeciw potrzebom i oczekiwaniom osób starszych w kontekście odczuwania przez nich satysfakcji życiowej.

Kluczem w wyborze czynników kształtujących satysfakcję życiową osób starszych były grupy czynników najczęściej wskazywane przez narratorów podczas rozmów, tj. subiektywna ocena zdrowia, sytuacja mieszkaniowa, miejsce zamieszkania, relacje rodzinne, relacje sąsiedzkie oraz poczucie użyteczności społecznej.

\section{Bibliografia}

Argyle M. (2004), Przyczyny i korelaty szcześcia, [w:] J. Czapiński (red.), Psychologia pozytywna. Nauka o szczęściu, zdrowiu, sile i cnotach człowieka, Warszawa, s. 165-203.

Błachnio A. (2017), Jakość i strategie życia w starości, [w:] A. Błachnio, K. Kuryś-Szyncel, E. Martynowicz, A. Molesztak (red.), Psychologia starzenia się i strategie dobrego życia, Warszawa. 
Błachnio A. (2019), Potencjał osób w starości. Poczucie jakości życia w procesie starzenia się, Bydgoszcz.

Boski P. (2010), Kulturowe ramy zachowań społecznych, Warszawa.

Braun-Gałkowska M. (2006), Nowe role społeczne ludzi starszych, [w:] S. Steuden, M. Marczuk (red.), Starzenie się a satysfakcja z życia, Lublin, s. 184-194.

Bugajska B., Timoszyk-Tomczak C. (2006), Człowiek stary wobec przyszłości, [w:] S. Steuden, M. Marczuk (red.), Starzenie się a satysfakcja z życia, Lublin, s. 61-89.

Czapiński J. (2004), Psychologiczne teorie szczęścia, [w:] J. Czapiński (red.), Psychologia pozytywna. Nauka o szczęściu, zdrowiu, sile i cnotach człowieka, Warszawa, s. 54-102

Czapiński J. (2017), Psychologia szczęścia: kto, kiedy, dlaczego kocha życie i co z tego wynika, czyli nowa odsłona teorii cebulowej, Warszawa.

Dalkey N.C., Rourke D.L. (1972), The Delphi Procedure and Rating Quality of Life Factors, Los Angeles, California.

Derbis R. (2008), Jakość życia: od wykluczonych do elity, Częstochowa.

Dubas E., Muszyński M. (1016), Obiektywny i subiektywny wymiar starości, Łódź.

Dubisz S. (2003), Uniwersalny słownik języka polskiego, Warszawa, s. 1502-1503.

Halicka M. (2004), Satysfakcja życiowa ludzi starych, Białystok.

Halicka M. (2018), Starzenie się społeczeństwa i w społeczeństwie, Pedagogika Społeczna, nr 3(69), s. $21-32$.

Halicka M., Halicki J., Kramkowska E. (2016), Starość: poznać, przeżyć, zrozumieć, Białystok.

Halicki J. (2010), Obrazy starości rysowane przeżyciami seniorów, Białystok.

Jachimowicz V., Kostka T. (2009), Satysfakcja z życia starszych kobiet, Ginekologia Praktyczna, nr 3.

Kanasz T. (2015), Uwarunkowania szczęścia. Socjologiczna analiza wyobrażeń młodzieży akademickiej o szczęśliwym i udanym życiu, Warszawa.

Kijak R.J., Szarota Z. (2013), Starość. Między diagnozq a działaniem, Warszawa.

Konecki K. (2000), Studia z metodologii badań jakościowych. Teoria ugruntowana, Warszawa.

Kuziak M., Rzepczyński S., Sikorski D., Sucharski T., Tomasik T. (2011), Słownik myśli filozoficznej, Bielsko Biała.

Nes R.B., Rpysamb E. (2016), Happiness in Behaviour Genetics: An Update on Heritability and Changeability, Journal of Happiness Studies, vol. 18, issue 5.

Papuć E. (2011), Jakość życia - definicje i sposoby jej ujmowania, Current Problems of Psychiatry, 12(2), s. 141-145.

Pędich W. (2002), Regionalne zróżnicowanie sytuacji ludzi starych na wsi, [w:] B. Synak (red.), Polska starość, Gdańsk, s. 231-285.

Pinquart M., Schindler I. (2007), Changes of Life Satisfaction in the Transition to Retirement: A Latent-Class Approach, Psychology and Aging, 22(3), s. 442-455.

Seligman M. (2008), The new area of positive psychology, wystąpienie TED, https://www.youtube. com/watch?v=9FBxfd7DL3E, dostęp: 11.12.2020.

Skrzypek E. (2000), Jakość i efektywność, Lublin.

Steuden S., Marczuk M. (red.) (2006), Starzenie się a satysfakcja z życia, Lublin.

Swagler M.A., Jome L.R.M. (2005), The Effects of Personality and Acculturation on the Adjustment of North American Sojourners in Taiwan, Journal Of Counseling Psychology, 52, s. 527-536.

Szarota Z (2013), Społeczno-demograficzne aspekty starzenia się społeczeństw, [w:] R.J. Kijak, Z. Szarota, Starość. Między diagnozq a działaniem, Warszawa, s. 19-22.

Szatur-Jaworska B., Błędowski P., Dzięgielewska M. (2006), Podstawy gerontologii społecznej, Warszawa. 
Świerżewska D. (2010), Satysfakcja z życia aktywnych i nieaktywnych osób po 60. roku życia, Psychologia Rozwojowa, t. 15, nr 2, s. 89-99.

Timoszyk-Tomczak C., Bugajska B. (2013), Satysfakcja z życia a perspektywa przyszłościowa w starości, Opuscula Sociologica, nr 2(4).

Zalewska A. (2003), Dwa światy. Emocjonalne i poznawcze oceny jakości życia i ich uwarunkowania u osób o wysokiej i niskiej reaktywności, Warszawa.

Zych A.A. (2006), Starość - starzenie się, [w:] T. Pilch (red.), Encyklopedia pedagogiczna XXI wieku, t. 4, Warszawa, s. 949-954. 